\title{
Foreword by the Incoming Editor
}

\section{The China Quarterly: Retrospect and Prospect}

\section{Chris Bramall}

The China Quarterly is in rude health. This owes much to the excellence of our contributors. It testifies to the work of our referees and editorial board, who receive nothing but our grateful thanks for their labour. It speaks eloquently of the painstaking care demonstrated by the Quarterly's superb editorial team (Rowan Pease, Raphaël Jacquet and Alison Surry), and our excellent production team at Cambridge University Press (in particular Ella Colvin, Rebecca Roberts and Carol Miller). And it is a tribute to the work of my predecessor Julia Strauss, who has stood down after editing the Quarterly between June 2002 and June 2011. Under Julia's direction, the journal has prospered. The volume of contributions has greatly increased, and a series of special issues have been expertly produced and well received. These achievements reflect Julia's wholehearted commitment to the journal, and the painstaking care she has devoted to selecting and crafting submissions. I speak for the whole Executive Committee in thanking her, and wishing her well during her sabbatical.

As for the future, I am committed to a high degree of continuity in editorial policy. For one thing, the sheer volume of submissions to the Quarterly mandates the continuation of a ruthless approach to the assessment process. Accordingly, submissions which are insufficiently original, methodologically deficient, or which deal with subject matter that is unlikely to be of interest to a majority of the readers of the Quarterly will not normally be sent to referees. Julia introduced this policy, and I shall continue with it. I do so with great reluctance for the last category of submissions, conscious that some articles of great scholarly endeavour will be rejected at the first hurdle as a result. There is not, however, any reasonable alternative for a journal which receives so many high-quality submissions. In addition, editorial policy will remain unchanged in the sense that The China Quarterly will continue to be a broad church. My own views on the development of Chinese society and its economy over the last century are a matter of public record. However, it is not my intention to proselytize, or to exclude genuine scholarship on ideological or partisan grounds. Contributions across all manner of ideological and methodological divides are therefore welcome.

In two important respects, however, I believe that the content of the Quarterly does need to change. First, we need to re-focus our output on those fields which are of most interest to our readers. During Julia's nine years, the range of papers published has been vast. Her stated aim on assuming the editorship was to expand the spectrum of articles published, and she undoubtedly succeeded. 
Nevertheless, the subject matter of the six most downloaded articles during the five-year period from 2006 to 2011 (listed below) is revealing:

(1) Susan Greenhalgh, "Missile Science, Population Science: The Origins of China's One-Child Policy";

(2) Erica Downs, "The Chinese Energy Security Debate";

(3) Yang Guobin, "Environmental NGOs and Institutional Dynamics in China";

(4) Jack Gray, "Mao in Perspective";

(5) Bonnie Glaser and Evan Medeiros, "The Changing Ecology of Foreign Policy-Making in China";

(6) Azizur Khan and Carl Riskin, "China's Household Income and Its Distribution, 1995 and 2002."

These subjects - politics, economic development, social justice, security and demography - have been the mainstay of the Quarterly over the last four decades, and they will continue to be so whilst I am editor. Indeed I should welcome more submissions in the fields of economics (especially macroeconomics), political science and foreign relations. By contrast, manuscripts dealing with Chinese history (by which I mean the period before 1978), religion, media and literature will be considered, but they are unlikely to be published unless they engage with issues of great significance.

I also have in mind a second change. The field of Chinese Studies has come to be dominated by research which is micro in orientation, which pays scant regard to the literature, and which is very uncritical of that literature with which it does engage. In all this, we are losing touch with policy concerns in favour of research which is narrow, ephemeral, or just plain dull. I therefore encourage submissions which engage with policy issues, or which offer a robust and critical perspective on conventional scholarship, rather than a mere recitation of fieldwork results. None of this is to say that micro studies will be unwelcome on the pages of this journal: high-quality fieldwork and primary research remain essential if we are to understand China. Nor should they be unwelcome; the Quarterly has been very successful over the last decade in the approach that has been taken. Nevertheless, a little more grand theory would not go amiss, and I hope that even those who inhabit the wilder shores of Chinese Studies will not feel inhibited from making their voices heard. 